\title{
RODA NA SAIA: HISTÓRIA, COSTURA E EDUCAÇÃO DE MULHERES NEGRAS PROFESSORA
}

RODA NA SAIA: HISTORY, SEWING AND EDUCATION OF BLACK WOMEN TEACHERS

https://orcid.org/0000-0002-4264-028x Rejane Lucia Amarante de Macedo A

${ }^{\text {A }}$ Universidade Federal Fluminense (UFF), Niterói, RJ, Brasil

Recebido em: 5 maio. 2021 | Aceito em: 29 ag. 2021

Correspondência: Rejane Lucia Amarante de Macedo (reluam30@hotmail.com)

\begin{abstract}
Resumo
A escrita deste texto é oriunda dos desdobramentos da pesquisa de Doutorado que a autora tem realizado no Programa de Pós-graduação em Educação da Universidade Federal Fluminense - UFF, em que pesquisa com mulheres negras professoras, articulando educação e os movimentos da costura. Traz como proposta desta escrita pensar como os trabalhos manuais da agulha possuem uma larga identificação com as mulheres negras e com o tipo de educação que recebem em Escolas Femininas até 1961. A opção teórico-metodológica é a pesquisa-formação, a partir de uma perspectiva autobiográfica. (JOSSO, 2007). Uma história particular que se entrecruza a muitas outras histórias de mulheres negras, incluindo as de sua família, experimentando os saberes da costura e do magistério em percursos de vidaformação.
\end{abstract}

Palavras-chave: história de mulheres negras; costura; educação profissional feminina.

\begin{abstract}
The writing of this text comes from the unfolding of the Doctoral research that the author has carried out in the Graduate Program in Education at the Fluminense Federal University - UFF, in which she researches black women teachers, articulating education and the sewing movements. The purpose of this writing is to think about how needle crafts have a broad identification with black women and with the type of education they receive in Women's Schools until 1961. The theoretical-methodological option is researchtraining, from a perspective autobiographical. (JOSSO, 2007). A particular story that intersects with many other stories of black women, including those of their family, experiencing the knowledge of sewing and teaching in life-training paths.
\end{abstract}

Keywords: history of black women; sewing; female professional education. 


\section{Introdução}

A escrita deste texto é oriunda dos desdobramentos da pesquisa de Doutorado que estou realizando no Programa de Pós-graduação da Universidade Federal Fluminense - UFF, em que pesquiso com mulheres negras professoras, articulando educação e os movimentos da costura. Sendo assim, trago como proposta desta escrita pensar como os trabalhos manuais da agulha possuem uma larga identificação com as mulheres negras ${ }^{i}$ e com o tipo de educação que recebem, utilizando a escrita autobiográfica como elemento problematizador. Narro uma história particular que se entrecruza a muitas outras histórias de mulheres negras, incluindo as da minha família, que experimentam os saberes e os fazeres da costura e do magistério em seus percursos de vida-formação.

Não se trata de uma "história única" (ADICHIE, 2019, p. 11), pois a considero sempre incompleta e isto me ajuda a pensar que existem muitas versões dela mesma. Cada vez que a narro, vou agregando retalhos de vida e aquilo que posso me tornar. (FOUCAULT apud, BUTLER, 2017, p. 45). Sou uma contadora de histórias e cada vez que proponho narrar a mim mesma, um "eu já implicado na temporalidade social" (BUTLER, 2017, p. 20), vou apresentando versões diferentes (ADICHIE, 2019, p. 11).

Escapo de uma história única a partir da descoberta, da conversa com outras mulheres negras e assim, abre caminhos para discussões específicas a respeito deste grupo (DAVIS, 2014). Daí a importância de trazer outras histórias dos cotidianos e dos afetos - "aquilo que se inventa com mil maneiras de caça não autorizada.” (CERTEAU, 2014, p. 38) Há muitas histórias silenciadas e estas me ajudam a compor a história que interessa a esta escrita. Penso que isto me ajuda a sentir o mundo, as relações e a sociedade.

Apresento então a vocês, parte da minha história de vida, utilizando as práticas de rememorar. São percursos de vida-formação, que dizem respeito a um "caminhar para sii"

[...] a proposta de se perceber o processo de investigação como um 'caminhar para si denota o processo inconcluso da investigação, ao mesmo tempo em que nos remete a nossa própria trajetória de vida neste mundo, envolvendo vários aspectos que foram historicamente apartados do processo investigativo, mas que se encontram nas nossas vidas e nas nossas escolhas, como emoções, relacionamentos, afetividades, trajetórias vividas, dificuldades enfrentadas, etc. (SILVA, 2012, p. 04).

Nesta caminhada vou, de certa forma, juntando outras histórias de mulheres negras, refazendo assim, minhas próprias trajetórias." (Ibidem). Então considero que a narrativa "não se entrega, pois conserva suas forças e depois de muito tempo ainda é capaz de se desenvolver”, 
afetando a vida das pessoas de diversas maneiras. (BENJAMIN, 1985, p. 204). O narrar histórias, a reconstrução, o ouvir e refletir sobre as histórias de vida-formação, envolvem diversos aspectos, dentre eles os políticos, éticos e estéticos. Quais escolhas serão feitas na produção dessa escrita?

Pensando em articular costura e escrita, compondo uma metáfora entre linhas, agulhas, papel e palavras, inicialmente apresento a vocês a costureira como uma artífice que "explora dimensões de habilidade, empenho e avaliação de jeito específico. Sustenta um diálogo entre práticas concretas e ideias.” (SENNETT, 2019, p. 20). A palavra costureira evoca inicialmente uma imagem, seja ela vinculdada à linha, agulha, máquina de costura, tecido e também a mulher. A costura foi por muito tempo considerada um trabalho apenas feminino, contudo considero importante problematizar esta questão no decorrer do texto.

Ainda articulando os movimentos da costura e escrita com os processos de vidaformação, proponho uma conversa para pensar o ser professora, que não será considerada, de forma natural, como uma profissão tipicamente feminina. É fundamental dismistificar o magistério com algo ligado a dom ou vocação. É importante também argumentar que a “divisão social do trabalho" é um lócus atravessado pelas "relações de poder." (BIROLI, 2018, p. 23).

Ao narrar os caminhos de ser professora, pretendo justamente problematizar essa questões, tomando como base uma tradição que acontecia na minha família e que hoje entendo como algo que por muito tempo determinou nossas escolhas profissionais. Com isso, "os caminhos que envolvem a opção inicial ou não pelo magistério e a identificação com a profissão" são aqui apresentados como relações de opressão de gênero, raça e classe. (DAVIS, 2014; HOOKS, 2013), assumindo uma postura interseccionaliii , pois não é possível tratar estes termos de forma isolada. Eles atravessam as experiências de mulheres negras de forma intensa. (COLLINS, 2017, p. 08), sendo aqui consideradas como relações estruturais que acabam reproduzindo as desigualdades.

A interseccionalidade também atravessa as histórias aqui narradas, levantando questões que ajudam na reflexão sobre como as mulheres negras tem suas experiências circunscritas pelo racismo, o sexismo, exploração de classe, dentre outros marcadores sociais. (Ibidem, 2017, p. 07). Além de luta, estas histórias anunciam os movimentos de resistências que se desdobram na minha vida e das mulheres da minha família. Sou uma mulher negra, costureira, professora e tantas outras coisas que vou escolhendo ser. São estes os caminhos que tenho experimentado e de certa forma, junto a outras mulheres negras, vou rompendo com a herança colonial e com as aspirações profissionais demarcadas para nós, 
reiventando a mim mesma. (DAVIS, 2014, p. 17).

A escrita desse texto, traz ainda como opção teórico-metodológica, a pesquisaformação, a partir de uma perspectiva autobiográfica ${ }^{\mathrm{i}}$, na qual "as narrações centradas na formação ao longo da vida revelam formas e sentidos múltiplos de existencialidade singularplural, criativa e inventiva do pensar, do agir e do viver junto." (JOSSO, 2007, p, 413). A vida é aqui narrada com "vários objetivos e de diferenciadas formas." (Ibidem).

Conforme afirma Benjamim (1985), a narrativa era, de certa maneira, uma forma de comunicação artesanal. Narrar e costurar são modos artesanais de composição que aqui seguirão articulados nessa escrita. Terão como matéria prima, as experiências de vida, as vozes e suas potências. Vão dizer de um tempo em que algumas mulheres negras detinham o saber da costura e, que rompendo com os modelos hegemônicos na divisão sexual do trabalho, se tornaram professoras, assumindo outros papéis na sociedade. (RAGO, 2018).

Mulheres negras que também tinham suas vozes silenciadas. (RIBEIRO, 2017) Quem podia falar? Quais discursos estavam autorizados? É possível pensar que:

[...] em toda a sociedade a produção dos discursos é controlada, selecionada, organizada e redistribuída por certo número de procedimentos que tem por função conjurar seus poderes e perigos, dominar seu acontecimento aleatório, esquivar sua pesada e temível materialidade. (FOUCAULT, 2012, p. 08).

A fala do autor ajuda-me a pensar que desde tempos atrás, existia uma autorização discursiva que excluia muitas vozes. isto oprimia determinados sujeitos, principalmente as mulheres negras. Penso que historicamente, a partir de movimentos de lutas e resistências, a narrativa atual foi ganhando novos contornos e desdobramentos. Mulheres negras foram rompendo com o silêncio inposto e ergueram suas vozes. (HOOKS, 2013). De certo modo, a narrativa perdeu um pouco das características iniciais propostas por Benjamin (1994), mas ainda pode ser pensada como uma forma de comunicação artesanal, de resitência e também como lugar de disputa.

Buscando então um relato de si mesma, a narrativa ganha força e se afirma, descobrindo que o "eu não tem uma história própria que não seja também a história de uma relação [...]" (BUTLER, 2017, p. 18). A relação entre as mulheres negras da minha família será aqui apresentada a partir do uso da metáfora de vestir a saia ${ }^{v}$, fazendo um jogo de todas as palavras (CERTEAU, 2014, p. 10). Estas trazem a tona os processos de formação que atravessam a minha história de vida e também a de outras mulheres negras professoras.

A saia é aqui pensada como uma costura bem elaborada, complexa e plural. Uma peça do vestuário que representa aqui um grande círculo de formação, como um tecido recortado e 
costurado no tempo/tempos em que a costura e o magistério foram considerados saberes e fazeres tipicamente de mulheres. Vestir a saia, aqui, representa um movimento de luta e resistência.

\section{Saia rodada na infância: lembranças das primeiras costuras}

Saia rodada na infância, diz muito sobre lembranças dos primeiros pontos de costura. Roupa de festa, roupa de menina e roupa que se movimentava com o vento. Girava com as saias. Lembro-me que minha mãe costurava saias rodadas com tecido e elástico na cintura. Eram coloridas, de estampas ou lisas. Minhas primas também vestiam estas saias. Minha mãe e tias aprenderam a costurar em família, mas também contam que a escola que frequentaram também ensinou a costurar. Foi lá que tiveram contato com a costura profissional e também com o fazer do bordado e das rendas.

É possível então pensar a costura como um percurso formativo na vida das mulheres negras? Para mim e minhas tias, a costura inicialmente se deu no "espaço privado e doméstico" (BIROLI, 2018, p. 10), pois foi em família que foram produzidos os primeiros pontos. Foi a partir de uma tradição familiar, iniciada por meu bisavô que foi pessoa escravizada, que a costura se desdobrou em nossas vidas. Nas tantas "relações de gêneros", atravessadas também por "relações de poder" (Ibidem), a costura que foi incialmente produzida em família por mãos de homens negros, passa com o tempo a ser uma das "maneiras de fazer" (CERTEAU, 2014, P. 35), exclusivamente das mulheres negras da minha família.

$\mathrm{Na}$ infância aprendi os primeiros pontos da costura manual e também vivi a experiência de costurar utilizando uma máquina de costura caseira. Era uma máquina antiga, que funcionava a pedal. Havia um certo ritmo para tocar a costura com o pé, movimentando o pedal da máquina. Minha mãe me alertou sobre isso, caso contrário seria impossível costurar à máquina.

Sobre a costura manual, fazíamos desde costuras simples quanto as mais elaboradas, incluindo também alguns pontos de bordado. Lembro-me que saíamos juntas: mãe, primas, tias e avó para comprar tecidos. Posteriormente nos reuníamos, geralmente na casa da minha avó para comapartilhar moldes, revistas e também para costurar juntas. Uma ensinava a outra.

As meninas da família não tinham escolha a não ser aprender a costurar. As mulheres também não tiveram escolha, pois isto acontecia a cada geração. Com isso, na dinâmica familiar, começava a ser produzido os lugares para as mulheres e possivelmente, ficava evidenciado a marca da "divisão sexual do trabalho ${ }^{\mathrm{v}}$ " (BIROLI, 2018, p, 10), pois a costura seria mais tarde uma opção de inserção no mercado de trabalho destinado somente as mulheres. 
Hoje percebo que de forma naturalizada as relações familiares eram atravessadas por relações de poder, destoando de "valores de referência igualitários." (Ibidem).

Butler cita Foucault, afirmando que aquilo que "posso ser, de maneira bem literal, é limitado de antemão por um regime de verdade que decide quais formas de ser serão reconhecíveis e não reconhecíveis.” (BUTLER, 2017, 35). Embora estes regimes de verdade possam decidir as maneiras de ser, isto não restinge as possibilidades de ruptura. Não se pode universalizar e muito menos determinar que isto afetará a vida das mulheres negras de um modo geral. Muitas rompem com estes regimes, ainda que sofram, de certa forma, os efeitos de suas atitudes. As relações com "os regimes de verdade, são antes de tudo, relações consigo mesma." Daí a necessidade de um postura crítica e reflexiva para romper com estes regimes. (Ibidem).

Nos movimentos de questionar a mim mesma, vou problematizando coisas e situações que de certo modo governaram a minha vida e das mulheres negras de minha família por muito tempo. Será que teríamos aprendido a costurar se não fosse este um fazer destinado as mulheres da minha família para que tivéssemos uma profissão e pudéssemos prover o sustento? Teríamos feito outras escolhas? Por muito tempo normas oficiais determinavam os epaços das mulheres negras, mas ao longo do tempo elas tem produzidos outros espaços individuais e coletivos. (FONSECA, 2018, p. 516).

As formas de educação no espaço familiar estão mudando. (LOURO, 2018, p. 444). Antes as meninas eram preparadas para os afazeres domésticos, para o magistério e para a costura. A geração de mulheres negras da minha família posterior a minha, ou seja minhas sobrinhas, não aprenderam, ainda, a costurar. Será que vou fazer com elas o mesmo que minha mãe e tias fizeram comigo quando experimentei a costura? Minhas sobrinhas estão se dedicando a outras práticas.

De certa forma está acontecendo alguma ruptura nos saberes familiares? Será que irão aprender a costurar também? Estas questões me atrevessam e fazem-me pensar sobre os cortonos de outros espaços para as mulheres negras do meu círculo familiar. Estão escapando de fato do perigo de uma história única assim como afirma ADICHIE. (2019, p. 11).

\section{Saia na gira: recordando os sons dos atabaques}

As saias na gira trazem-me a recordação dos sons do atabaque. Foi no terreiro de umbanda que vi, ainda criança, as saias mais rodadas do mundo. Elas estavam vivas aos vento, nos corpos das mulheres e na roda de saias. Complementavam as danças e os rituais. Por que não dizer que a saia, dentro deste contexto, seria um certo tipo de entidade que bailava no chão 
do terreiro feito de areia de praia? É a lembrança impalpável, viva e potente. A vida que se embalava na dança das mulheres de saias na umbanda.

A religião também foi algo que aprendi em família. Meu bisavô, além da costura, também trouxe consigo, depois do período pós-abolição, a Umbanda. Lembro-me das festas no terreiro, da minha mãe, avós e tias costurando as saias da gira lá mesmo, após os rituais. $\mathrm{O}$ terrreiro era "um lugar de socialização acolhedora." (CAPUTO, 2012). Algumas crianças participavam dos rituais e outras ficavam do lado de fora. Lembro-me que brincávamos e cantávamos cantigas de roda que se misturavam aos sons dos atabaques. Esta brincadeira se remetia ao cultos dos orixás. Chegávamos a imitar suas vozes, gestos e maneiras de dançar. (Ibidem).

Era comum que durante os rituais de umbanda as saias ficassem rasgadas. Girar ao som dos atabaques provocava, prossivelmente, contato e atrito entre os corpos vestidos pelas saias. Tecidos variados, rendas, metros e metros de tecidos. As mulheres vestiam as saias para embalar seus corpos

Fui batizada na religião católica pela mãe de santo do terreiro. Ao mesmo tempo em que frequentávamos o terreiro de umbanda, também assistíamos as missas da religião católica. Era como se uma coisa se interligasse a outra, estabelecendo assim o que Miranda (2010, p, 130), relata como uma falsa sensação de "tolerância religiosa." Ficava a ideia da "ausência de intolerância religiosa" devido ao sincretismo ${ }^{\mathrm{vii}}$ e cordialidade que produzíamos ao experimentar as duas religiões. "Tais premissas partilhavam da ideia da ausência de conflito e da presença de harmonia existente entre partes opostas, porém complementares e hierarquicamente dispostas no espaço público.” (MIRANDA, 2010, p. 130).

As saias de gira tinham muitas cores e tecidos variados. Os pontos de umbanda e os sons dos atabaques ditavam os ritmos que embalavam a gira. As saias eram muito bem costuradas, feitas com muitos e muitos metros de tecidos. O embalar dos rituais incluíam os modos de girar e manusear a saia. As mulheres negras da minha família vestiam as saias de gira.

Ainda sobre minha infância, sempre estive muito envolvida com a música. Estudava no conservatório, teoria musical e violão. Com isso, quando ia ao terreiro ficava muito encantada com os sons do atabaque. Eu queria muito aprender a tocar, mas fui alertada por meu avó, que também frequentava o mesmo terreiro, que as meninas e mulheres não podiam tocar atabaque na umbanda. Era um fazer dos homens. Sentia-me frustrada e com isso, ficava batucando na minha perna quando ouvia um atabaque tocar. Com isso, mesmo na religião, havia uma "divisão sexual do trabalho", estabelecendoo "fronteiras nas atribuições entre homens e mulheres." 
(BIROLI, 2018, p. 21).

Minha mãe parou de frequentar o terreiro quando eu tinha mais ou menos 9 anos de idade. A crise no casamento a levou a procurar a religião evangélica. Havia o que Caputo chama de “demonização da religião.” (2012). Meu pai tinha muito preconceito com relação a umbanda e culpabilizava a religião, atribuindo a ela culpa pelo fracasso do casamento. Dizia que minha mãe não cuidava da casa, pois costumava ir sempre no terreiro.

\section{Roda na saia: os saberes de mulheres negras professoras}

A roda na saia vai desenhando uma proposta de pesquisa que aposta nas conversas ${ }^{\text {viii }}$ com mulheres professoras negras sobre seus processos de vida-formação. As mulheres negras professoras que vestem a saia e que fazem delas uma vestimenta ou um apetrecho para para afirmar seus corpos coletivos. E por que não dizer que a forma circular da saia rodada, que pode ser recortada em tecido acompanhando um ângulo de $360^{\circ}$, compõe um grande círculo, que abriga as lembranças, tornando-se um lugar de união, de aprendizado, costuras e também de formação. Roda na saia. Saia costurada. A costura que se articula com os processos de formação entre estas mulheres negras.

É importante destacar que houve um processo histórico da educação das mulheres e em especial para escrita desse texto, destacarei a educação profissional feminina. A partir do século XIX, começou a se dar o aprendizado de um ofício nas instituições escolares, que se somava a perspectiva da construção da moral e da civilidade na época. O Presidente Nilo Peçanha cria em 1909 em 10 estados, as escolas de aprendizes e artífices. No âmbito regional são criadas, por decreto, escolas profissionais masculinas e femininas por inúmeras cidades do Estado, dentre elas, na capital do Estado - Niterói, uma escola profissional feminina e duas profissionais masculinas. (DUTRA, 2013; SOUZA, 2018).

Entre o período de 1924 e 1962, a educação profissional estava voltada para os filhos dos trabalhadores, pretendendo a criação de uma massa proletária especializada e ordeira que não se entregasse à desordem e à anarquia. (DUTRA, 2013; SOUZA, 2018). Primeiro os meninos tiveram acesso a escola e posteriormente, as meninas. Já por volta do ano de 1930, meninos e meninas teriam a cesso ao ensino profissional e também cursariam aulas teóricas que ajudariam no bom desempenho da profissão escolhida e também frequentariam aulas de educação física, moral, cívica e musical. Havia muito interesse de criação destas escolas devido a industrialização e a necessidade de ter mão-de-obra barata para ocupar as vagas de emprego. 
Segundo Ferreira, "o ingresso das mulheres nas escolas de primeiras letras, no século XIX, marcava o despontar do feminino para vida pública, como também, o início de uma trajetória de lutas e conquistas, desse gênero, na sociedade brasileira.” (FERREIRA, 1998, p. 01). Com isso, algumas mulheres começaram a ter acesso a escolarização, favorecendo, de certa forma, alterações no seu destino de mulher-esposa-mãe, pois muitas começaram a trabalhar na esfera pública, atuando como costureiras, lavadeiras e assumindo outros ofícios fora da esfera privada. (LOURO, 2018, BIROLI, 2014). Outras conseguiram ainda, dar continuidade aos seus estudos e ingressaram em uma carreira profissional.

Houve também um tempo em que a costura fazia parte da educação feminina como parte integrante do plano de estudos/currículo do sistema educacional entre os séculos XIX e XX. As habilidades com a agulha, os bordados, as rendas, as habilidades culinárias e outros afazeres domésticos preparavam as moças para serem agradáveis aos seus maridos. (LOURO, 2018, p. 466). Minha mãe e tias narram suas histórias no período em que estudaram na Escola Feminina Aurelino Leal - Niterói/ RJ durante a década de 60 do século XX. Suas histórias de formação trazem a marca da educação para as meninas de uma determinada época, principalmente aos saberes da costura, bordado e outras práticas consideradas femininas.

Não posso deixar de expor que este percurso histórico não é aqui apresentado a partir de um pensamento mono-categórico ${ }^{\text {ix }}$, pois não diz respeito a categoria mulher como algo pautado na universalização e muito menos na essencialização. (COLLINS, 2017. DAVIS, 2014). Neste recorte histórico aqui apresentado, muitas mulheres negras não tiveram acesso a educação que acontecia em instituições escolares que buscavam a profissionalização, tendo assim o seu destino traçado para os afazeres domésticos, para o casamento, para a solidão ou ainda para ofícios que não eram ensinados nos espaços de educação formal. Outras, assim como aconteceu comigo, aprendeu algum ofício a partir dos saberes que circulavam em suas famílias.

No período colonial e escravocrata, as mulheres negras trabalharam seja nas lavouras, senzalas ou ainda nas casas dos seus senhores. Elas eram consideradas sem gênero, submetidas aos mesmos trabalhos que os homens negros escravizados, sem o direito a maternidade e eram consideradas, a partir da proibição do tráfico de pessoas escravizadas vindas da África, como reprodutoras. (DAVIS, 2014, p. 17). Havia uma repressão violenta que as afetava, mas elas não se submeteram a condição de pessoas escravizadas por vias de regras, muito menos se fixaram como vítimas. Muitas se rebelaram, fugiram e se juntavam em comunidades negras, onde exerciam papéis sociais fundamentais. 
No período pós-abolição elas continuaram no mercado de trabalho, mesmo que ainda tendo que atuar em profissões que eram desqualificadas. Buscavam seu sustento, podiam se casar, ter filhos ou não e lutavam por ocupar espaços na sociedade. Agarrava-se a qualquer oportunidade de trabalho. Tudo isto retratava uma época em que as relações de gênero eram bastante hierarquizadas e ainda permeadas fortemente pelas relações de poder que destinavam a maioria das mulheres a um não-lugar na sociedade brasileira (DEL PRIORI, 2018; RAGO, 2018; LOURO, 2018; BIROLI, 2018).

Trago a seguir fragmentos das histórias das mulheres negras da minha família que apontam seus caminhos de acesso a educação, bem como o relato de vivências familiares. Estas histórias trazem pistas e indícios que apontam para o fato de que mesmo passado várias décadas após a abolição, ainda existe uma continuidade entre as posições que homens e mulheres ocupam na sociedade. (BIROLI, 2014, p. 35).

Minha mãe conta que começou a estudar e foi matriculada na Escola Profissional Feminina Aurelino Leal, localizada no bairro do Ingá/Niterói. Estudou lá até 1962. Era uma escola só para meninas. Passava o dia inteiro na escola, aprendendo diversas matérias e participando das oficinas. Ela escolheu as oficinas de corte e costura, bordados e rendas. Essa escolha podia ser feita, mas era obrigatório participar. Minha mãe fugiu das oficinas de flores e de chapéus. Ela já costurava antes mesmo de ser matriculada na escola e com isso, pensou que poderia se aprimorar, melhorar a costura e ter uma profissão na vida. Foi considerada uma das alunas mais talentosas na costura e no bordado, por isso fazia trabalhos para o Palácio da Guanabara, costurando e bordando peças como toalhas, lençóis e colchas.

Depois que concluiu os estudos na Escola Profissional Feminina, precisou mudar para outra instituição e foi matriculada na Escola Nilo Peçanha para fazer o curso de formação de professores. Chegaria a um nível mais elevado de estudos, mas era uma escola privada. Não havia naquela região o cruso de formação de professores ofertado em escolas públicas. Então ela costurava para fora e assim, conseguia pagar seus estudos. Outras meninas da turma também faziam isso.

Minha mãe seria a primeira da família a ser professora. Uma mulher negra professora dos anos iniciais. Durante o curso teve aulas de didática e de métodos para ensinar bem letras e números. Também aprendeu a cuidar de crianças, pois uma boa professora teria que fazer isso. A Educação Doméstica ainda se fazia presente nos planos de estudos dos cursos de Educação Feminina. (LOURO, 2018). Na sala em que estudou só havia meninas. Segundo elas, poucas eram negras. O curso de formação de professores era coisa "feminina" naquela época. 
(FERREIRA, 1998). Passou por muitas dificuldades, pois era também outra escola muito rígida na disciplina. Tinha que usar saias pregueadas lá na altura do calcanhar, blusa com combinação, cabelos sempre presos e bem penteados.

Os bons modos eram muito cobrados das meninas. Eram ensinadas a ser professoras e moças prendadas para a boa sociedade. Havia muitas normas e cobrança com relação ao comportamento das meninas. Minha mãe relata que ficou muito de castigo porque enrolava suas saias em protesto quando saia da escola. As meninas daquele tempo precisavam se submeter a rigidez do sistema escolar, mas viviam muitas experiências quando se reuniam na praça localizada a frente da escola. Fumavam e bebiam escondido.

Ela e suas colegas eram apontadas nas ruas como futuras professoras, pois o uniforme escolar as identificava assim. Este mesmo denunciavam, de certa forma, que aquelas meninas eram boas moças, pois este era um pré-requisito para exercer o magistério. Minha mãe sabia que seria difícil ser professora porque era pobre e negra. Não sabia se alguma escola iria dar emprego a ela e por isso, estudava e também costurava para fora. De qualquer forma teria algum tipo de sutento. Fazia costuras para uma pequena confecção com minha avó e tias. Passou por muitas dificuldades na época, mas o que aprendeu na Escola Feminina Aurelino Leal nas aulas de corte e costura, ajudava no sustento da casa.

Se formou professora em 1964 e começou a trabalhar em escolas muito afastadas na zona rural da cidade de Magé. Pegava carona, acompanhada por outras professoras, para poder chegar até a escola em que atuava. Continuava a costurar e se aventurou a costurar vestidos de noiva. Isto rendia uma renda maior. Chegou a um ponto da minha mãe, sendo a irmã mais velha, de sustentar a casa quando meu avô adoeceu. A costura e o magistério abriram caminhos, à muitos impensáveis, para que ela pudesse ter uma condição de vida melhor.

Ainda assim, não posso deixar de enfatizar que minha mãe ocupava espaços pensados, naquela época, como espaços femininos. No entanto, muitas mulheres negras eram impedidas de acessá-los. A partir de muitas lutas, ela e muitas outras mulheres negras conseguiram acessar o ensino, derrubando diversas barreiras que as impediam de atuar em determinadas profissões. (LOURO, 2018, p. 445).

\section{Saia rasgada: costura, magistério e trabalho feminino}

A saia rasgada representa aqui as rotas de fuga que vou construindo com outras mulheres negras professoras. Os movimentos de uma saia me ajudam a pensar sobre questões relacionadas à costura, magistério e trabalho feminino. No entanto, diante deste longo percuso 
feito até aqui a saia foi se rasgando pelo caminho. Preciso costurá-la, para isso vou contar com a colaboração das outras mulheres que me acompaham neste percurso de escrita.

As mulheres negras da minha família costuravam em casa para assim, como outras, complementar o orçamento doméstico. (RAGO, 2018, p. 581). Elas também trabalharam em fábricas, costurando desde roupas mais básicas, até roupas sociais. Eram mulheres que romperam com as normas, pois deixavam de ocupar os espaços privados, em que se apresentavam em suas "individualidades concretas e particularidades” (BIROLI, 2014, p. 32), para redefinir seus lugares na esfera pública, considerados como espaços em que se deram novas formas de interação social entre homens e mulheres. (RAGO, 2018, p. 585). Nestes outros espaços tiveram que lutar contra as diferenças hierarquizadas entre os sexos. (BIROLI, 2014, p. 32),

Quando nos reuníamos para costurar, conversavámos sobre diversos assuntos, mas uma fala recorrente era sobre casamento. Assim como as outras meninas da minha família, fui preparada para me casar cedo, ser uma boa mãe e dona de casa. O mundo dos afetos era também um mundo de muitas opressões, em que as tradições familiares eram atravessadas pelas relações de poder. Os papéis convencionais de gênero (BIROLI, 2014, p. 34), selaram de certa forma o meu destino.

Naquela época não refletia sobre estas questões, pois estava efetivamente envolvida com o ambiente familiar, a tal ponto de seguir exatamente o roteiro que foi determinado para minha vida. Fonseca me ajuda a problematizar tudo isso, quando fala sobre "os esteriótipos colocados nos valores coloniais que fazem parte das relações familiares." (FONSECA, 2018, p. 517). Aprendi a costurar e também ingressei no curso de formação de professores aos 16 anos de idade. Minha mãe e tias eram professoras e, assim como elas, fui me encantando pelo fato de poder trabalhar fora em meio período do dia. Assim poderia ter a minha renda, cuidar da minha casa, filhos e família que viria a constituir. Considero importante destacar que todas as minhas tias e mãe sempre trabalharam fora e com isso, não eram sustentadas por seus maridos.

Embora defendessem a tradição familiar de serem costureiras e professoras, as mulheres da minha família sempre buscaram o trabalho na esfera pública e uma educação para a "emancipação" (RAGO, 2018, p. 585). Um fato que tinham em comum, que também é importante aqui destacar, é que a maioria delas se divorciaram e com isso, tiveram que assumir o sustento do lar. De certa forma haveria o que Louto chama de incompatibilidade entre casamento e trabalho feminino? (LOURO, 2018, p. 454).

Parece um tanto contraditório, pois ao mesmo tempo em que preparavam as mais jovens 
para o casamento e o trabalho, elas mesmas não mantiveram a tradição de se manterem vinculadas a uma família conjugal tradicional (FONSECA, 2018, p. 521), formada por homem, mulher e filhos. Neste caso, se divorciaram e o trabalho feminino deixava de ser mero suplemento, para se tornar o sustento principal da casa. (Idem, 2018, p. 516).

Retomando uma questão aqui levantanda, a costura e o magistério foram definidos e até certo ponto ainda são como "trabalhos, competência e lugar de mulher." (BIROLI, 2018, p. 21). As divisões de gênero, raça e classe tem papéis definidos na determinação das formas de educação pelas quais as mulheres negras são submetidas? A educação preconizava, principalmente para as mulheres pobres e negras, a possibilidade de ascensão social e econômica. No entanto, até que ponto elas escolhem de fato que tipo de trabalham desejam experimentar? Muitas ainda precisavam escolher entre o casamento e o sustento, pois não podem se dedicar apenas a família e com isso, sofrem diversos tipos de opressão e violência por parte dos homens.

Louro afirma em sua obra a existência de uma "feminização do magistério" (LOURO, 2918, p.449), que se dá a partir de muitos fatos, dentre eles, o de que o ensino deixaria de ser apenas ofertado para meninos e contemplaria também as meninas a partir do século XIX. Neste período os homens ocupavam o magistério, mas com a chegada das meninas nos bancos escolares, as mulheres se tornaram necessárias. Para educar as meninas era preciso rever a profissionalização do magistério (FERREIRA, 1998; LOURO, 2018) e com a industrialização, os homens começaram a ter outras oportunidades de trabalho para além do magistério que le rendiam salários mais altos. Existia também outra questão que era considerada como fundamental: a identificação natural da mulher com a atividade do magistério. $\mathrm{O}$ destino da mulher de ser mãe era articulado ao magistério, pois este seria uma extensão da maternidade com relação aos cuidados e ensinamentos. (LOURO, 2018, p. 450).

Com relação as mulheres negras que vão se tornando professoras, estas rompiam com determinados esteriótipos sociais que buscavam demarcar e limitar os lugares socias destas mulheres, como sendo exclusivamente os de domésticas, cozinheiras, prostitutas entre outras profissões desqualificadas. "Para isso, deveriam lutar contra todas as formas de manifestação das relações de poder, tanto nas fábricas quando nas escolas, nos sindicatos, nos grupos sociais e políticos e mesmo no próprio lar.” (RAGO, 2018, p. 582- 597).

Embora tenham sido subjugadas e criticadas, pois havia resitência com relação a moral, a sexualidade e também ao despreparo, as mulheres negras foram ocupando seus espaços na educação. A norma oficial ditava que a mulher deveria se resguaradar em casa (FONSECA, 
2018, p, 517), mas no entanto, as mulheres negras sempre ocuparam os espaços públicos de trabalho. O mesmo aconteceu com as mulheres da minha família e muitas outras que encararam desde sempre a costura e o magistério como profissão. Davam conta dos serviços domésticos e ainda, se assumiram como mulheres negras trabalhadoras.

\section{Arremates finais na saia: uma costura feita a muitas mãos}

A ação de costurar se mistura aqui com os aspectos poéticos e políticos da costura, de evocação da memória e também da realização que tem com a educação Os aspectos poético e políticos que a ligam com uma memória particular estão presentes na educação, no momento em que nos planos de estudos/ currículos escolares, a costura fazia parte da do cotidiano de alunas de escolas profissionais femininas. Além das disciplinas escolares, as habilidades manuais eram consideradas fundamenrais para a formação moral de moças que seriam integradas posteriormente a sociedade no início e meados do século XX.

A ação de costurar está diretamente ligada a uma memória familiar das mulheres negras da minha família, sobre seus processos de formação e de como a costura as unia. Memórias repetidas e deslocadas do cotidiano, no passado que se torna presente quando a memória é atualizada a partir de suas lembraças. Estas memórias também me ajudaram a pensar sobre como a costura atravessou e fez parte do plano de estudos/currículo da educação da Escola Feminina Aurelino Leal entre os anos de 1924 e 1962.

Portanto, para a escrita deste texto, precisei buscar caminhos que permitissem aproximar a costura para o campo da escrita. Após as discussões aqui apresentadas foi possivel problematizar sobre como trabalhos manuais da agulha tiveram durante o período de funcionamento das Escolas Fenininas Profissionais uma larga identificação com as mulheres negras e com o tipo de educação que recebiam. Havia divisão sexual do trabalho.

Ao narrar uma história particular que se entrecruza a muitas outras histórias de mulheres negras, incluindo as da minha família, apresentei um percurso formativo em que os saberes e os fazeres da costura e do magistério se entrecruzam a diversas questões que vão dizer sobre as relações de opressão e poder.

Acredito que a perspectiva da interseccionalidade ajudou-me a compreeender a relevância do conhecimento para a luta por liberdade e icentivo a justiça social. (COLLINS, 2017, p. 07). Foi o esforço de desnaturalizar algumas experiências vividas em família que estiveram estruturadas a parir de relações estruturais de poder e opressão. As relações entre raça, classe e gênero como sitemas de poder, colaboram com a divisão social do trabalho, ajudando a demarcar ainda mais, certas fronteiras que vão delimitar os papéis socias das 
mulheres negras.

Por fim, as histórias aqui narradas falam das experiências familiares com costura e magistério entre mulheres negras que, apesar de estarem submetidas a regimes de opressão, conseguiram ter acesso a escolaridade, partindo para o trabalho na esfera pública. Elas também deram conta do trabalho doméstica e do cuidado com seus filhos. As narrativas, repletas de elementos que ajudam a porpor diversas discussões apontam ainda para a necessidade de continuar a narrar histórias de mulheres negras.

Narrar histórias para escapar das armadilhas de uma história única. Narrar com o corpo, assumindo isto como um ato político que ajuda a erguer a voz de mulheres negras, silenciadas historicamente, mas que rompem com os cenários de opressão e violencia. Como diz Chimamanda, "as histórias importam. Muitas histórias importam. As histórias foram usadas para espoliar e caluniar, mas também podem ser usadas para empoderar e humanizar." (ADICHIE, 2019, p. 32).

Sigo contando histórias. Elas me fazem quem eu sou.

\section{Referências}

AGABEM, Giorgio. O que é um dispositivo? Ilha, Santa Catarina, $2^{\circ}$ sem., 2005.

ADICHIE, Chimamanda Ngozi. O perigo de uma única história. Tradução Julia Romeu. São Paulo: Companhia das Letras, 2019.

BENJAMIN, Walter. Magia e técnica, a arte e política: ensaios sobre literatura e história da cultura. $7^{\mathrm{a}}$ edição, São Paulo: Brasiliense, 1985.

BIROLI, Flávia. Gênero e desigualdades:limites da democracia no Brasil. São Paulo, SP: Boitempo, 2018.

BUTLER, Judith. Relatar a si mesmo: crítica da violência ética. Trad. Rogério Bettoni. $1^{\mathrm{a}}$ ed; $3^{\text {a }}$ reimp. Belo Horizonte: Autêntica, 2017.

CAPUTO, Stela Guedes. Educação nos terreiros e como a escola se relaciona com crianças de candomblé. Rio de Janeiro: Pallas, 2012.

CERTEAU, Michael de. A invenção do cotidiano - artes de fazer. Petrópolis, RJ: Editora Vozes, 2014.

COLLINS, Patrícia Hill. Se perdeu na tradução? Feminismo negro, interseccionalidade e política emancipatória. Parágrafo, [S.1.], v. 5, n. 1, p. 6-17, jun. 2017.

DAVIS, Ângela. Mulheres, raça e classe. Tradução de Heci Regina Candiani. São Paulo: Boitempo, 2016, 244p. 
DEL PRIORE, M. História das Mulheres no Brasil. Coordenação de Textos de Carla Bassanezi, 10 ed. $6^{a}$ reimpressão. São Paulo: Contexto, 2018.

DUTRA, Vivian Machado. De Nilo Peçanha a Aurelino Leal: conflitos inter-oligárquicos em torno da Escola Profissional Feminina de Niterói (Primeira República). Centro de Filosofia e Ciências Humanas Faculdade de Educação Programa de Pós-Graduação em Educação. Rio de janeiro, 2013.

FERREIRA, Andres Teresa Brito. A mulher e o magistério: razões da supremacia feminina (a profissão docente em uma perspectiva histórica. Tópicos Educacionais, [S.1.], v. 16, n. 1-3, abr. 2017. ISSN 2448-0215. Disponível em:

<https://periodicos.ufpe.br/revistas/topicoseducacionais/article/view/22455>. Acesso em: 4 maio 2021. doi:https://doi.org/10.51359/2448-0215.1998.22455.

FONSECA, Cláudia. Ser mulher, mãe e pobre. In: DEL PRIORE, M. História das Mulheres no Brasil. Coordenação de Textos de Carla Bassanezi. 10 ed. 6 a reimpressão. São Paulo: Contexto, 2018.

FOUCAULT, Michel. A ordem do discurso: aula inaugural no Collège de France, pronunciada em 2 de dezembro de 1970. Tradução de Laura Fraga de Almeida Sampaio. São Paulo: Edições Loyola, 2012.

HOOKS, Bell. Ensinando a transgredir: a educação como prática da liberdade. São Paulo Martins Fontes, 2013.

JOSSO, Marie Christine. A transformação de si a partir da narração de histórias de vida. Revista Eletrônica PUCRS, Porto Alegre/RS, ano XXX, n. 3 (63), p. 413-438, set./dez. 2007. Disponível em:

<https://revistaseletronicas.pucrs.br/ojs/index.php/faced/article/view/2741/2088>. Acesso em: 10 abr. 2021.

JOSSO, Marie Christine. Histórias de vida e formação: suas funcionalidades em pesquisa, formação e práticas sociais. Revista Brasileira de Pesquisa (Auto)biográfica, v. 5, n. 13, p. 40-54, 28 jun. 2020.

LOURO, Guacira Lopes. Mulheres na sala de aula. In: DEL PRIORE, M. História das Mulheres no Brasil. Coordenação de Textos de Carla Bassanezi, 10 ed. $6^{\text {a }}$ reimpressão. São Paulo: Contexto, 2018.

MIRANDA, Ana Paula Mendes de. Motivo presumido: sentimento, identidade religiosa e estigmatização escolar no Rio de Janeiro. Dilemas-Revista de Estudos de Conflito e Controle Social, Rio de Janeiro, n. 1, p. 139-164, 2015. Edição Especial.

RAGO, Margareth. Trabalho feminino e sexualidade. In: DEL PRIORE, M. História das Mulheres no Brasil. Coordenação de Textos de Carla Bassanezi, 10 ed. $6^{a}$ reimpressão. São Paulo: Contexto, 2018. 
RIBEIRO, Djamila. O que é lugar de fala? Belo Horizonte: Grupo Editorial Letramento: Justificando, 2017.

ROMAO, Tito Lívio Cruz. Sincretismo religioso como estratégia de sobrevivência transnacional e translacional: divindades africanas e santos católicos em tradução. Trab. linguist. apl., Campinas, v. 57, n. 1, p. 353-381, Apr. 2018. Available from $<$ http://www.scielo.br/scielo.php?script=sci_arttext\&pid=S0103$18132018000100353 \& \operatorname{lng}=$ en\&nrm=iso $>$. access on 04 May 2021.

SENNETT, Richard. $O$ artífice. Tradução de Clóvis Marques. - $6^{\mathrm{a}}$ Ed. - Rio de Janeiro: Record, 2019.

SKLIAR, Carlos. Elogio à conversa (em forma de convite à leitura). In: RIBEIRO, T; SOUZA, R. SAMPAIO, C. S. (Org.) Conversa como metodologia de pesquisa: por que não? . Rio de Janeiro: Ayvu, 2018.

SILVA, Márcia Alves da. Discutindo gênero através do trabalho artesanal. IX Anped Sul. Seminário de Pesquisa em Educação da Região Sul. 2012. Disponível em: <http://www.ucs.br/etc/conferencias/index.php/anpedsul/9anpedsul/paper/viewFile/439/810>. Acesso em: 10 abr. 2021.

SOUZA, Elisabete Gonçalves de. Arquivos históricos escolares: uma proposta de organização dos fundos das escolas do trabalho de Niterói, RJ. Disponível em: $<$ https://www.encontro2018.rj.anpuh.org/resources/anais/8/1529727803_ARQUIVO_Arquivo shistoricosescolaresartigo18-6-18.pdf >. Acesso em: 17 abr. 2021.

\footnotetext{
i Segundo Biroli “a identidade do grupo 'mulheres' vem sendo posta em questão de maneira sistemática pelas feministas negras e pelas feministas socialistas [..]" (BIROLI, 2018, p.09). Estes debates passam a operar com "noções mais complexas das experiências e das necessidades das mulheres, vistas em suas diferenças e do prisma das desigualdades de classe, raça, etnia, sexualidade e gênero." (Ibidem). Com isso, durante a escrita do texto utilizarei a expressão mulheres negras para reafirmar que este determinado grupo, além de viverem situações de discriminação e preconceito relacionadas a questão de gênero, também enfrentam mecanismos de exclusão e diferenciação com relação a raça e classe. (DAVIS, 2016; RIBEIRO, 2017).

ii Josso (2007) desenvolveu este conceito em sua tese de doutorado em 1991

iii Segundo Collins, a interseccionalidade pode ser pensada como projeto de conhecimento em que raça, classe, gênero e sexualidade estão interconectados. Sua organização estrutural e aspirações se reforçam uma a outra. (COLLINS, 2017, p. 09). No decorrer da escrita do texto serão evidenciadas, de forma interseccional, "a interrelação de raça, classe, gênero", a partir de experiências cotidianas. (Ibidem, p. 08).

iv A proposta aqui apresentada sobre uma escrita autobiográfica diz respeito "as narrações centradas na formação ao longo da vida revelam formas e sentidos múltiplos de existencialidade singular-plural, criativa e inventiva do pensar, do agir e do viver junto." (JOSSO, 2007.413.)

v A saia como um dispositivo que Foucault denomina como um conjunto heterogêneo, que inclui qualquer coisa, linguístico e não linguístico, tendo sempre uma função estratégica concreta que se estabelece sempre em uma relação de poder. (AGAMBEN, 2005, p. 01).

${ }^{v i}$ Segundo Biroli, "falar de divisão sexual do trabalho é tocar no que vem sendo definido, historicamente, como trabalho de mulher, competência de mulher, lugar de mulher. E, claro, nas consequências dessas classificações." (BIROLI, 2018, p. 21).

vii $\mathrm{O}$ sincretismo ganhou muita força, pois para tentar escapar as opressões com relação às práticas religiosas, os negros prestavam culto às imagens da religião católica, associando-as suas entidades das religiões de matrizes africanas. A respeito disto Romão diz que "com o tempo, os negros foram assimilando cada vez mais a cultura brasileira e a religiosidade dos portugueses, e assim foram descobrindo como poderiam empregar os nomes dos santos católicos, para na verdade cultuarem suas divindades ancestrais.” (ROMÃO, 2018, p.364).

viii Skliar apresenta a conversa como "um conglomerado de rostos, gestos, vozes e silêncio. É o corpo que conversa, não o conhecimento prévio.” (SKLIAR apud RIBEIRO; SOUZA; SAMPAIO, 2018, p. 11).
} 
ix Davis (2014) enfatiza que a mulher negra é submetida a certas experiências que contextualizam a opressão de gênero nas conjunturas do racismo. Historicamente foram submetidas à invisibilidade. Ribeiro enfatiza que "as mulheres negras vêm lutando para serem sujeitos políticos e produzindo discursos contra hegemônicos." (RIBEIRO, 2017, p. 21). 